\title{
TOLSTOI E HEIDEGGER: DA MORTE INDIFERENTE À MORTE PRÓPRIA
}

\author{
Ecio Elvis Pisetta
}

UNIRIO

\begin{abstract}
Resumo: O texto oferece modesto estudo acerca da experiência da morte a partir da novela de Leon Tolstoi (1828-1910), A morte de Ivan Ilitch (1886) e de alguns conceitos desenvolvidos pelo filósofo alemão Martin Heidegger. Tolstoi desnuda a vida, tal como ele a vê. E o faz através de uma crítica à sociedade. Esta, para manter o status, foge e oculta toda real experiência da morte bem como da vida. Tolstoi não poupa descrições da vida pública como aquela que cultiva uma vida e uma morte indiferente ou impessoal. Neste contexto, o personagem representa o dramático nascimento do ser humano para sua singularidade. Desta forma, consideraremos o percurso apresentado pelo próprio livro, servindo-nos de descrições onde a sociedade e a ciência, a vida cotidiana e seus raciocínios e a experiência de uma morte própria possam ser visualizados.
\end{abstract}

Palavras-chave: Existência; morte; sociedade; filosofia; Tolstoi; Heidegger.

\begin{abstract}
The text presents an interpretation of death's experience based in the novel written by Leo Tolstoy (1828-1910) called The Death of Ivan Ilytch (1886) and some ideas developed by the German philosopher Martin Heidegger. There, Tolstoy exposes life as he sees it, which means, through some social and moral critiques. For maintaining its status, society gets away and hides any real experience of death and life. So understand Heidegger too. Tolstoy does not spare descriptions of public life as such one that cultivates some indifferent, nobody and impersonals life and death. In this context, Ivan represents the dramatic human birth to their uniqueness. Like a didactic method we consider the way presented by the novel, using some descriptions where science, society and its moral behavior, the everyday life and its thoughts and the experience of death itself can be viewed and discussed.
\end{abstract}

Keywords: Existence; death; society; philosophy; Tolstoy; Heidegger.

Escrevo sobre o mínimo parco enfeitando-o com púrpura, jóias e esplendor. É assim que se escreve? Não. Não é acumulando e sim desnudando. Mas tenho medo da nudez, pois ela é a palavra final (LISPECTOR, 1984, p.93).

\section{Considerações iniciais}

O texto oferece um modesto estudo acerca da experiência da morte a partir da novela de Leon Tolstoi (1828-1910), A morte de Ivan Ilitch (1886). Tolstoi desnuda a vida corriqueira, tal como ele a vê. E o faz assumindo o ponto de vista do personagem que, morrendo, dessa mesma vida se afasta gradativamente. $\mathrm{O}$ que se torna visível a partir deste desnudamento? A possibilidade efetiva da morte desvela na consciência do personagem a vida 
que considerava como sendo a sua. A leitura e interpretação desta novela são capazes, inclusive, de transformar a compreensão do leitor. Provavelmente Tolstoi tinha isso em mente. Alguns pontos passíveis de reflexão nos chamam a atenção: a vida cotidiana e atarefada de todos; a vida daqueles que convertem o personagem em objeto de estudo e/ou de atenção diferenciada; a vida do personagem em relação ao seu trabalho, no contato com as coisas e com as pessoas que lhe eram próximas; a vida desejada por Ivan e sua vida de fato vivida; esta, ainda, em relação à outra vida - estranha - continuamente ignorada e, por fim, honestamente sentida como não vivida! No entanto, o melhor será despertar no leitor a visão para a tensão existencial que ganha corpo no personagem: trata-se de um personagem fictício no qual repercute algo de essencial.

É possível ao leitor não desejar reverter o destino de Ivan e dispor-se a uma nova compreensão de vida e de morte? Como se mostra o desnudamento de vida e de morte na obra literária citada? Em geral, através de uma crítica à sociedade. Esta, para manter o status, foge e oculta toda real experiência da morte bem como da vida. Como ferrenho crítico das instituições de seu tempo, o autor não poupa descrições da vida pública como a que cultiva uma vida e uma morte indiferente ou impessoal. Mas há mais a considerar. Contra este predomínio do público e impessoal na compreensão da vida e da morte encontramos o dramático nascimento do ser humano em sua singularidade. Trata-se do nascimento de um drama no palco de nosso pensamento, tal como um som diferenciado que chama a atenção e nos convoca a um caminho.

No entanto, quer isso dizer que a vida social impede toda genuína vida? E que fora desta sociedade e de sua indiferença haveria um ser humano vivendo sua pessoalidade e singularidade? Não estaríamos caindo no equívoco de imaginarmos uma vida humana sem a sociedade? Ou de propormos algum modelo moral e utópico de vida? A crítica social desenvolvida pelo autor visa a uma destruição da sociedade ou à sua transformação? Há que se ter cuidado com estas questões. Desvelar aquilo que permanece oculto em todos os protocolos ou comportamentos sociais não significa eliminar estes mesmos comportamentos e protocolos. Acabaríamos por engendrar outros tantos e nos contradizer. Parece-nos mais significativo a conquista de outra perspectiva capaz de examinar o direito de ser e os fundamentos da sociedade restituindo a esta sua finitude. Nós assumimos a compreensão deste desvelamento (alétheia, verdade) - bem como de outros conceitos filosóficos - a partir das reflexões do filósofo alemão Martin Heidegger. Na atenção ao filósofo podemos dizer que desvelamento não significa a retirada enfática de um véu ou de todos os véus de tal forma que tudo viesse a ser descoberto e que o 'visível' se sobrepusesse a todo 
'invisível' (Cf. HEIDEGGER, 2006 a, p.294)ํ․ Além de ser uma tarefa impossível e, por isso, presunçosa, ela pretenderia eliminar tudo o que é enigmático e misterioso e, portanto, tudo o que é vital. A própria força dos fenômenos seria submetida, por exemplo, aos raciocínios planificadores e responsáveis pela vida pública onde tudo o que perturba e atrapalha tende a ser corrigido. A nosso ver, então, não haveria mudança substancial da compreensão. No entanto, a partir do velamento apresenta-se algo que atrapalha e deve constantemente atrapalhar! Nossa reflexão consiste em tornar transparente a presença do velamento ou, por outra, de tudo o que atrapalha e se mostra como estorvo. O que permanece oculto detém presença decisiva na compreensão do que permanece desoculto. Aquele não se constitui como uma negação deste. Antes, seu sentido e complemento. Assim, co-pensamos o velamento, o oculto e o mistério, como a força e a dinâmica constituinte do desvelamento. Ambos perfazem fenômeno de unidade. Alétheia, a verdade, é desvelamento e velamento. Neste jogo desnuda-se um fundo continuamente encoberto pela vida social e que se mostra como o mais próprio: a vida humana apresentada a partir da morte, vida que dirige seu olhar para a sociedade e a pode ressignificar, bem como aquela vida que se dirige para sua própria dinâmica de autoconstituição. Morrendo, o personagem alcança a inteireza! O convite de Tolstoi para optarmos ou nos decidirmos por esta vida reside, a nosso ver, nesta última sentença da novela. A partir da morte a vida se completa. Apresentamos, dessa forma, o fio condutor de nosso trabalho.

Cabe ainda uma observação. Ensaiaremos interpretação filosófica de obra da literatura internacional. Com que propósito? Não vemos nisso alguma espécie de hibridismo que desfavoreça uma e outra. O que almejamos, talvez, habite um lugar que anteceda tanto a filosofia quanto a literatura formalmente compreendidas. Este 'lugar nenhum' pode ser assim apresentado: desejamos, antes de qualquer coisa, prepararmo-nos intelectualmente para a gravidade do tema, o da experiência da morte. Esta gravidade move o literato e o filósofo. E buscam dizê-la cada um a seu modo. Nosso modo de ler e de dizer pode ser expresso como 'ontológico ou filosófico ou ontológico-existencial', para distingui-lo de outras possibilidades de apropriação do tema inclusive da tradição filosófica. Assim, decidimos não nos estender em demasia em certas discussões para não perdermos o sentimento fundamental para o qual a obra nos acorda. Reconhecemos nisso uma deficiência metodológica e uma aposta pedagógica: a de que o leitor, em algum grau, seja tocado pelo interesse que move os autores mencionados. Nosso interesse filosófico é convocado, desafiado e delimitado justamente pela força da palavra do artista Leon Tolstoi.

1 '1. Verdade no sentido mais originário é a abertura da presença [Dasein] à qual pertence a descoberta dos entes intramundanos. 2 . A presença é e está, de modo igualmente originário, na verdade e na nãoverdade'. 
Nosso esquema de trabalho: 1 Considerações iniciais; 2 Filosofia e existência; $3 \mathrm{O}$ percurso da morte de Ivan: resumo e alguns comentários; $3.1 \mathrm{~A}$ vida de Ivan; $3.2 \mathrm{O}$ aparecimento da doença; 3.3 Consciência da morte; $3.4 \mathrm{~A}$ identidade da morte; 3.5 A agonia de Ivan; 4 Considerações finais: uma reflexão filosófico-sociológica; Referências bibliográficas.

\section{Filosofia e existência}

O texto versa sobre a morte. Esta se mostra como um objeto investigativo um tanto insólito. Tal estranheza deve-se ao seguinte: ela não se submete, meramente, às investidas conceituais oriundas da ciência médica, da lógica, da sociologia, do saber cotidiano, etc. O que ocorre é que, de modo crescente, o aparente objeto de nossa investigação adquirirá corpo, tomando as rédeas de sua própria manifestação. O objeto, então, torna-se justificadamente o fundamento que nos funda em nossa empreitada, como fenômeno de base condutor da análise. Semelhante atitude perturba o teórico e pesquisador usual. E com razão. De modo semelhante, encontramos a mesma atitude na mente de Ivan, à medida que ele toma consciência que ninguém sabe, de fato, o que está a acontecer com ele!

A partir da experiência da morte elabora-se reflexão acerca da existência humana em seu caráter "prévio". Não daquela existência, aparentemente imediata, que nos é acessível e proporcionada por algum campo das ciências naturais, por exemplo. Nem da existência proporcionada pela experiência corriqueira à medida que a compreendemos como evidente em si mesma. Nestes âmbitos, que sempre podem ser ampliados, melhorados, sofrendo especializações constantes, progride-se visando certa segurança ou controle no conhecimento e manipulação dos objetos. Visamos a um desnudamento destes saberes para que se torne visível, em certa medida, o modo de ser do humano, seu Dasein ${ }^{2}$ (presença, ser-aí, 'ser humano') servindo-nos de termo-chave da filosofia heideggeriana - prévio a toda instalação prática ou teórica. Desta forma não ignoramos os mais diversos trabalhos que visam a quantidade e a qualidade da vida humana, mas desejamos conduzir a reflexão para outra direção que, à sua maneira, pode também contribuir para uma compreensão mais ampla daquelas experiências já citadas. Em todo caso, a fim de atendermos um pouco melhor aos diversos interesses que nos motivam, indicamos alguns poucos estudos ${ }^{3}$. Estes, por um

${ }^{2}$ Cf. HEIDEGGER, Martin. Ser e tempo. Petrópolis : Vozes, 2006 a, §2, p. 42; §9, p.95-96; § 63, p.397.

${ }^{3} \mathrm{Cf}$. Diversos estudos surgiram preocupados com a elaboração de uma compreensão mais ampla de vida e morte. Além de nossa pequena bibliografia, citamos aqui: ARIES, Philippe. O homem diante da morte. Rio de Janeiro : Ed. Francisco Alves, 1989; FREUD, S. Reflexões para os tempos de guerra e morte. Rio de Janeiro : Imago, 1974; KÜBLER-ROSS, Elizabeth. Sobre a morte e o morrer. São Paulo : 
lado, colaboram na compreensão do tema e, por outro, distinguem-se do mesmo. Buscar trânsito conceitual em meio a tantas perspectivas e sem perder o foco é de suma importância.

\section{O percurso da morte de Ivan: resumo e alguns comentários}

A compreensão da existência humana de que trataremos é, apenas, o simples e puro fato de sermos, de estarmos aqui e ali, ontem e hoje, continuamente engajados num mundo de atividades possíveis. Esta situação ultrapassa toda determinação sem recusá-la e possui estrutura transcendente 4 . Não podemos meramente ser e estar situados no mundo como coisas dadas e evidentes, pois já nos movimentamos no espaço da compreensão de nós mesmos. Existir é compreender. Sabemos de nós mesmos e, de alguma forma, sabemos de nossa morte. Essa nossa existência nos angustia ou será que experimentamos, de maneira mais acurada, que nesta angústia manifesta-se o imo de nossa existência? No segundo caso, a angústia não se mostra como algo acidental e fortuito.

Estamos, então, a direcionar nosso olhar para a vida a partir da experiência singular e própria da morte. É na possibilidade da experiência antecipada da morte que justificamos e fundamentamos esta inversão (Cf. HEIDEGGER, 2006 a, \$62, p.388). A partir desta inversão vemos uma repercussão da vida sobre ela mesma e, neste sentido, uma ampliação de sua compreensão.

\subsection{A vida de Ivan}

A novela inicia-se com a chegada da notícia da morte de Ivan Ilitch, juiz de instrução que fez carreira como funcionário público e faleceu vítima de uma doença, aos 45 anos. Seus amigos juristas, neste momento, estavam mais preocupados com as possíveis novas promoções do que com a notícia de falecimento. Afinal, 'quem morreu foi ele [Ivan] e não eu' (TOLSTOI, 1997, p.9). Esta frase expressava a sensação tranquilizadora que se abateu sobre seus antigos colegas de trabalho pelo fato de estarem vivos. As obrigações de irem ao velório, desejar os pêsames à viúva, etc., enfim, atender ao protocolo, eram desagradáveis. Todos queriam que tudo logo terminasse para retornarem à

Ed. Martins Fontes, 1989; ELIAS, Norbert. A solidão dos moribundos. Envelhecer e morrer. Rio de Janeiro : Jorge Zahar editores, 2001.

${ }^{4}$ HEIDEGGER, Martin. 0 que é metafísica? In: Marcas do caminho. Petrópolis: Vozes, 2008, p.132. Aí se lê: 'A metafísica [metá, trans] é 0 acontecimento fundamental do ser-aí [Dasein, presença, "ser humano"]. Ela é o próprio ser-aí'. 
vida de sempre. Uma vida momentaneamente quebrada pela impertinência da morte.

Mas que vida era essa, a vida de sempre e de todos? Era a vida que, exemplarmente, narra-se como sendo a vida de Ivan Ilitch, "simples, vulgar e terrível" (TOLSTOI, 1997, p.19): relacionar-se com os que estão acima socialmente, levar vida correta, isto é, aquela esperada e que correspondia ao cargo, cumprindo o dever e atendendo às obrigações funcionais características. Como juiz de instrução aplicava as leis do estado numa eficiente mecânica e buscava viver uma vida 'esperada pela sociedade', de acordo com sua função e cargo. Mas a mesma vida correta era também 'terrível'. E o que isto significa? Algo que nela acontece possui tamanha artificialidade que soterra e estagna a própria vida. Toda a concentração da vida voltava-se para o mundo burocrático. Ivan, que queria levar uma vida correta, via no trabalho um abrigo contra os imprevistos da vida, contra aquelas surpresas que desestabilizavam a tranquilidade ou a vida esperada. Desenvolveu, então, um método particular de trabalho: afastava tudo que não pertencesse ao trabalho, à questão, e que não pudesse ser colocado num papel timbrado. 'Em tudo tratava de excluir o que fosse fresco e vitalizante, aquilo que sempre perturba o processo normal da burocracia, e só admitir relações funcionais (...)' (TOLSTOI, 1997, p.37). Um dia casou-se, e... por que não deveria casar-se?! Já casado e com filhos teve de se haver com as necessidades práticas de dinheiro e como consequência com a busca de uma promoção dentro da hierarquia do serviço público. Conseguiu a promoção e, devido a ela, uma transferência. Ele e a mulher, com quem tinha vários atritos, fizeram planos juntos, partilharam os mesmos sonhos, sonhos de uma nova vida bem ao gosto da sociedade. Tomado por esta ilusão partilhada, Ivan seguiu na frente para a nova cidade. Lá providenciou ele mesmo uma casa e começou todos os trabalhos de reforma, decoração e compra da mobília. Estava feliz. Queria arrumar uma casa onde 'tudo teria um caráter requintado e elegante, isento de vulgaridade, quando pronto' (TOLSTOI, 1997, p.34). Nesse trabalho árduo chegou, acidentalmente, a bater 'com as costelas no trinco da janela. Machucou-se um pouco, mas a dor passou e ele se sentiu muito bem disposto' (TOLSTOI, 1997, p.35). Ficou muito contente com o resultado de seu trabalho. E da mesma forma a família que logo se transferiu para a nova casa. Mas, comenta Tolstoi:

$\mathrm{Na}$ realidade era apenas aquilo que geralmente se encontra nas casas de gente remediada que quer parecer rica e apenas consegue fazer com que se assemelhem extraordinariamente umas às outras. Tapeçarias, ébanos, plantas, pesados bronzes polidos, tudo aquilo que a gente de certa classe possui para parecer com outra gente dessa mesma classe. Sua casa era tão comum como as outras que nunca seria notada, mas para ele tudo parecia excepcional (TOLSTOI, 1997, p. 35-36). 


\section{2 $\mathrm{O}$ aparecimento da doença}

Foi então que apareceu um gosto esquisito na boca e uma sensação desagradável no lado esquerdo do ventre. Dirigiu-se ao médico. Este o tratou profissionalmente, da mesma maneira como ele mesmo tratava os que o procuravam (como mais um, como 'coisa). Ivan percebeu, pela primeira vez, a indiferença dos outros. Foi examinado, analisado à distância sob o ocular de uma pretensa objetividade. Nada do que dizia ou perguntava ao médico era relevante, a não ser aquelas respostas que atendiam estritamente ao que lhe era demandado e que podiam, numa folha de papel timbrado, serem registradas e interpretadas sob aquele ponto de vista. Mas Ivan sentia dor e percebia que nenhuma pergunta feita pelo médico era realmente importante! Havia uma só questão importante: 'o caso é sério ou não’? (TOLSTOI, 1997, p.43).

Mas o médico não tomou conhecimento dessa pergunta
despropositada. Do seu ponto de vista não era o paciente que
estava em causa, a verdadeira questão consistia em decidir
entre um rim recalcitrante, uma bronquite crônica e uma
apendicite (TOLSTOI, 1997, p.43).

Ivan atormentava-se com tudo isso. Voltou para casa. Tudo era triste, melancólico. A dor que ele sentia, dor surda, ininterrupta, adquiriu uma nova significação. Ela não cessava e desestabilizava-o. Tentou resultados melhores com vários outros médicos. Obteve outros diagnósticos e nenhuma melhora. Desta forma,

não se iludia: alguma coisa terrível, nova e mais importante do
que tudo o que lhe acontecera antes na vida, se efetuava
dentro dele e só ele percebia. Os que viviam ao seu redor não
compreendiam ou não queriam compreender, pensando que
tudo no mundo continuava como de costume. Isto, mais do
que tudo, atormentava Ivan Ilitch (TOLSTOI, 1997, p.47).

Mesmo assim não desistiu e tentava desviar-se dessa dor nos jogos com os amigos e no trabalho. Mas estas coisas já não interessavam como antes. Aos poucos perdeu o gosto por tudo aquilo que antes o ocupava e distraia e que preenchia a sua vida. Sentia cada vez mais solidão. Suas atividades o entretinham cada vez menos e o que ele sentia interessava menos ainda aos outros. Os amigos o olhavam 'como a um homem cujo lugar está para vagar' (TOLSTOI, 1997, p.48). Caçoavam, brincavam, minimizavam o que lhe ocorria 'como se a pavorosa, terrível e inaudita coisa que incessantemente vivia dentro dele, sempre a roê-lo e a arrastá-lo, irresistível, fosse um divertido tema para brincadeiras' (TOLSTOI, 1997, p.48).

De repente tudo se transformou. Ivan percebeu que todas as respostas procuradas pelos médicos, pelos amigos e por ele mesmo estavam 
equivocadas. Algo mais sério ocorria com ele. Não era nada com o apêndice ou com o rim. A questão 'é de vida e... morte. Sim, a vida estava comigo e agora vai indo embora, vai indo e não posso impedir. Pois é. Por que me iludir?' (TOLSTOI, 1997, p.54). Ivan tinha agora consciência de que o que estava chegando era a morte.

\subsection{Consciência da morte}

Mas a morte é uma experiência inimaginável! Surgiu então a necessidade de buscar um sentido, algo como uma resposta para esta estranha dor, a dor da morte e o que ela anunciava. Afinal, pensava Ivan, 'por que eu?' No capítulo IV vem à tona o conflito que irrompia na alma de Ivan: Por que isto estava acontecendo justamente com ele? Como entender a morte que o invadia? Ivan se lembrou do passado, das aulas de lógica do tempo de colegial e do menino que era. Neste contexto ocorre o diálogo entre a vida e a dor de Ivan Ilitch e a indiferença, isto é, as verdades lógicas, universais, válidas para todos e afastadas da vida. Mesmo sabendo que estava para morrer, Ivan não podia e não conseguia compreender esta ideia. Era impossível compreender este saber - sabia que ia morrer! - porque o pensamento que pensava nele, e que ele se acostumou a venerar durante toda a sua vida, era de outra ordem. Lembrou do manual de lógica. 'Caio é homem, os homens são mortais, logo Caio é mortal' (TOLSTOI, 1997, p.57). A evidência do que se passava o abatia:

Que Caio - o homem abstrato - fosse mortal, estava
perfeitamente certo, mas ele não era Caio, não era um
homem abstrato, era uma criatura perfeitamente separada de
todas as outras (TOLSTOI, 1997, p.57). Que sabia Caio do
cheiro dessa bola de couro listada que Vânia [Ivan] tanto
adorava? (...) É impossível que eu tenha de morrer. Seria
horroroso demais (TOLSTOI, 1997, p.57).

Qual a textura deste horror? Que 'todos' devem morrer mostra-se como uma evidência lógica. Mas que 'eu' deva morrer assemelha-se a um erro, um equívoco, uma impossibilidade. Afinal, apenas os outros ou os homens abstratos é que morrem! A consciência do eu resiste a tudo que a ultrapassa! No horror também se manifesta, como um efeito colateral, a consciência da solidão e do abandono, características daquilo que é percebido como particular e irremissível. Ao mesmo tempo manifesta-se aquela certeza indeterminada de quem diz 'não sei a hora, mas sei que há a hora' (PESSOA, 2007, p.82). Esta hora já não pode mais ser pensada por Ivan como algo abstrato, indiferente e calculável. Para esta hora não havia preparo. Ela diferia completamente do modo como havia orientado, preparado e sonhado a sua vida. 
Se tivesse de morrer como Caio, eu saberia. Uma voz interior me diria, mas nada disso havia em mim, e eu e todos os meus amigos sabemos que o nosso caso é inteiramente diferente do de Caio. Agora, está aí a morte! (...) Não pode ser. É impossível! Mas está aí. Como? Como se poderá compreender uma coisa dessas? (TOLSTOI, 1997, p.58).

De fato, ninguém morre como Caio! Ninguém morre como num silogismo! Ivan tropeçara em toda a sua vida na maior de todas as falácias, a da lógica. Ele percebeu que a vida que ele sempre vivera era uma vida razoável e correta, isto é, recheada de saberes comprováveis para todo mundo. Neste momento, no entanto - momento da dor e da doença - vê-se diante de uma situação ímpar. Esta reivindica um saber ilógico e que não pode ser comprovado por todo mundo. $\mathrm{O}$ fato de todos morrerem não explica nem propicia um conhecimento efetivo sobre a sua situação. $O$ fato de todos serem mortais nunca preparou Ivan para a sua morte! $\mathrm{Na}$ lógica mostra-se o universal, mola do saber em geral e, de modo especial, de todo saber institucionalizado. Mas no âmbito em que Ivan se encontrava e a partir do que estava sentindo, a resposta silogística era resposta nenhuma. Porque Ivan não era um homem abstrato, não era qualquer um que se encontrava fora de uma vida efetiva, fora de um engajamento real em alguma atividade. Ele era um homem que tinha história (os homens são históricos, e não coisas!), tinha vida própria e exercia um trabalho determinado, tinha relacionamentos e compromissos. 'Ivan' não era um conceito, uma categoria geral. Podemos imaginá-lo repetindo as palavras de J. L. Borges: 'E não quero que seja patético; quero que seja uma confidência que faço a cada um de vocês; não a todos, mas a cada um, porque "todos" é uma abstração, enquanto "cada um" é algo verdadeiro’ (BORGES, 1987, p.10).

Ivan percebia a estranha situação em que se encontrava. Percebia que não tinha linguagem para isso e que o mundo público e comum o dominara até então. Sofria, porque este mesmo mundo não tinha autoridade nenhuma diante desta novidade que irrompia. E ninguém o compreendia.

A certeza lógica e também cotidiana da morte, expressa no silogismo, é ambígua. A ambiguidade reside no seguinte: sabemos de nossa morte tanto quanto sabemos de qualquer outra morte. Ou seja, não sabemos de fato da morte de modo singular, isto é, como a 'minha' ou a 'tua' morte possível. Tal saber permanece obscuro. Este, aqui reivindicado, distingue-se do saber meramente empírico e do saber lógico-categorial. Afinal ninguém pode fazer a experiência da própria morte! Nem deduzi-la a partir de premissas maiores! Mas como podemos dela saber? Pois sabemos! Por meio de um saber antecipado da morte. Enveredamos por um caminho ontológico-existencial. Antecipadamente dela sabemos como possibilidade e não como realidade efetiva. Declinaremos deste saber ontológico-existencial se o considerarmos como 'menos saber' e nos pautarmos apenas pelo saber empírico com as coisas ou 
pela lógica. O saber antecipado acerca da morte mostra-se como o único possível para corresponder àquela voz estranha que clama e que quer ser ouvida no personagem Ivan! No fundo trata-se de um modo de saber velado, mas presente em todo ser humano. Talvez este âmbito da antecipação e da possibilidade nos pertença de modo mais próprio que qualquer outro saber! É também um modo de saber que raramente irrompe em nossa consciência. Ao contrário, no saber cotidiano da morte realiza-se um nivelamento de todo saber e de toda compreensão da vida: a morte e a vida são compreendidas como qualquer outra coisa (lógica). $\mathrm{O}$ que vale é a forma silogística e não o conteúdo de cada experiência. A morte é banalizada fenomenalmente, perdendo ou ficando encobertos seus aspectos fundamentais que expõem a singularidade do ser humano. Mas,

Enquanto fim da presença [Dasein, 'ser humano'], a morte é a possibilidade mais própria, irremissivel, certa e, como tal, indeterminada $e$ insuperável da presença. Enquanto fim da presença, a morte é e está em seu ser-para o fim (HEIDEGGER, 2006 a, \52, p.335).

Uma socialização e conscientização lógicas da morte (ou da vida!) trazem, a fortiori, o encobrimento da morte singular e própria. Também podemos dizer que toda certeza lógica - sem ignorar seus proveitos - traz consigo a fuga de uma genuína experiência da morte. São os véus múltiplos colocados sobre o real. 'O impessoal encobre o que há de característico na certeza da morte, ou seja, que é possivel a todo instante. Junto da certeza da morte, dá-se a indeterminação de seu quando' (HEIDEGGER, 2006 a, \52, p.334). A morte é possível a cada momento. É presente e real para cada ser humano enquanto é, isto é, enquanto vive ou existe. Uma consciência deste tipo - sem comparação, apesar de acessível a cada um - desespera nossa comum razão, ávida de continuidade e de respostas, de certezas e seguranças, ou seja, de controle. Por isso, rapidamente, buscamos aconchego nas mais diversas ocupações e preocupações da vida cotidiana (Cf. HEIDEGGER, 2006 a, \40, p. $255 \mathrm{ss}$ ), soterrando ou ocultando este fato bruto da vida. Mas por que a vida cotidiana precisa mascarar este seu fato bruto? Possui este fato bruto alguma força que possa corroer a vida costumeira? A certeza cotidiana da morte é, em geral, uma certeza que foge deste genuíno e radical fato bruto de nossa existência. Como? Transformando a morte numa certeza incerta; em algo que não nos diz respeito por estarmos vivos; propiciando uma fuga da possibilidade real da morte; convertendo-a, continuamente, em idéias, conceitos, abstrações genéricas. Pois 'o ser-para-a-morte é essencialmente angústia’ (HEIDEGGER, 2006 a, \$53, p. 343). Na vida social o ser humano foge deste fato. Foge do fato intransponível de seu ser. A descoberta deste âmbito de onde se foge (que continuamente reivindica presença!) e que corresponde ao mais próprio de nosso ser, bem como o compromisso 
explícito por assumi-lo, possuem a característica de uma opção ou decisão pelo que é mais próprio. A morte cobra singularidade.

\subsection{A identidade da morte}

Desesperado, Ivan tenta novamente fugir da dor no cumprimento de seu trabalho. Eram novos véus para encobrir a dor. Mas ela voltava. Ela, a dor, e o seu sem sentido que convoca peremptoriamente à singularização. A morte, a partir deste momento, sofre uma mudança de tratamento: ela é 'Ela'. 'E ele de novo começava a perguntar se só Ela era verdadeira' (TOLSTOI, 1997, p.59). Todas as atividades cediam diante da presença da morte. Somente Ela é verdadeira? Que há de movediço, de ruína e de 'certeza' nisso? Que possibilidades de sentido se ocultam nesta afirmação? A presença dela, da morte, e de seu Nada, como a última experiência da existência humana? Tudo é passageiro e ilusório, menos esta presença? Então todas aquelas respostas, advindas das mais diversas instituições, seriam grandes equívocos, grandes véus para se sobreporem a esta realidade última inventando uma vida burguesa, confortável, segura, duradoura e sem dor? Então o fundo último da vida e da existência humanas é um sem fundo, um Nada, a morte? $\mathrm{E}$ poderíamos pensar nesta realidade extrema como também sendo o princípio e o começo de toda vida humana? Estas afirmações apenas fazem sentido a partir da compreensão antecipada da morte! Afinal vive-se, trabalha-se, faz-se seja lá o que for para construir algo de duradouro - como uma ilha - frente à possibilidade intransponível da morte! Um começo que se trabalha muito para ocultar! Ter que se haver com a morte?! A morte ficava invisível nas distrações e ocupações da vida de Ivan. Mas ela sempre estava ali, sempre atravessava os véus, estava sempre roendo, surgindo ao menor aborrecimento. Somente Ela é verdadeira. Verdadeira: ela não passa, ela revela e mostra a veleidade de toda segurança institucional. Ela desassossega.

No terceiro mês a doença despertava um mal-estar nos outros e nele mesmo. Ivan tornou-se uma 'vaga' a liberar. Deveria deixar os vivos descansarem! Tinha dificuldades para dormir, comer, fazer as necessidades. Dependia completamente dos outros. Seu único conforto era Guerassim, um mujique que o servia. Dizia este como réplica às queixas do patrão: 'O senhor está doente, é quanto basta' (TOLSTOI, 1997, p.62). Ivan via no mujique aquele que não precisa acobertar os tristes eventos. Talvez, também, pensando em Tolstoi, uma crítica à sociedade erudita daquele tempo e um elogio à vitalidade do que é simples. Pois o que mais atormentava Ivan era a mentira que todos repetiam e aceitavam, a de que ele não estava para morrer, que estava somente doente, e que isto iria passar. A negação do passageiro e finito se mostra como uma grande mentira! E dizer a verdade como falta de tato social! Nessas mentiras o terrível ato da morte era reduzido a um 
incidente fortuito, desagradável, quase indecoroso (como alguém que entra numa sala espalhando mau cheiro), e isso era devido ao próprio decoro que durante toda a sua vida ele procurara manter. Viu que ninguém teria pena dele, porque ninguém queria sequer compreender aquela situação (TOLSTOI, 1997, p.65). Só Guerassim compreendeu e se apiedou (TOLSTOI, 1997, p.65).

O que era para ser compreendido? A situação humana no mundo, exposta pela vinda da morte. Guerassim não disfarçava os fatos com palavras evasivas nem mentiras. Sua compreensão não seguia nenhum modelo racionalista, cientificista, isto é, não possuía nenhuma estrutura lógicoargumentativa. Tolstoi, como Dostoievski, viam na erudição de seu tempo um caminho de propagação do nihilismo que tudo achatava e banalizava. A saída ou a salvação estaria na atenção e no retorno à terra, ao simples e limitado, àquelas experiências frágeis, vitais, 'espirituais' e inexplicáveis para o erudito, ou seja, na situação finita da condição humana. Guerassim representa um modo de relacionar-se com a vida desconhecido para Ivan.

Mas a dor não o abandonava. Antes o desesperava. Chamava essa dor de 'dor de angústia' (TOLSTOI, 1997, p.68), uma dor que não se limitava mais ao corpo. Era uma dor que não tinha mais um 'quê' para doer. Não tinha mais um ponto fixo, um objeto, para o entendimento interpretar como sendo a causa da dor. Era uma dor que só doía. Dor sem causa ou razão suficiente. Tudo era dor. O ser de Ivan era dor. Por meio dela ele aguardava o inevitável. Chegava a suplicar pelo fim, mas se arrependia, porque queria viver. Ivan sofria porque não aceitava a morte. Queria a vida tal como antes. Queria algo que era irreal, uma casca, algo artificial, ou seja, uma vida sem morte. Tal como a vida impessoal que antes vivia. No entanto, a dor e a morte não terminavam. Nada as superava. 'Chorou pelo seu desespero, pela sua solidão terrível, pela crueldade do homem, pela crueldade de Deus, pela ausência de Deus'; '(...) chorava porque não havia e não podia haver resposta’ (TOLSTOI, 1997, p.78).

$\mathrm{Na}$ morte, Ivan vivia a experiência do fim de todas as certezas, seguranças e fundamentos. Vivia a perda e a presença de uma existência sem nada de seu, inclusive sem Deus. Vivia o abandono. Não aquele apenas das pessoas. Mas também de todos os valores e saberes.

Nesta situação, Ivan dialogava com uma voz interior, talvez uma nova compreensão da própria vida, talvez a morte. Ivan lhe dizia que queria viver, viver sem sofrer, viver como vivia antes, isto é, bem e agradavelmente. No entanto, em seu desespero extremo, já não lembrava mais como tinha sido a sua vida. Tinha esquecido! A memória agora convocada tem outro tom e outra mensagem. Por que esquecia aquele tempo que foi o mais longo de sua vida, aquele em que trabalhava e se projetava socialmente? Este tempo e seus valores se dissipavam e ficavam apenas as agradáveis recordações do tempo de menino. Depois da infância a vida esvaziou-se. Mas o que a infância tinha de 
verdadeiro e que sobrevivia como algo de último e de primeiro? Precisamos ver aqui algo mais do que um mero saudosismo infantil. $A$ infância possui a memória da arquitetura da existência, de seu tempo e espaço. Dessa força primitiva gestada na infância falam também outros escritores.

Para o criador, com efeito, não há pobreza nem lugar mesquinho e indiferente. Mesmo que se encontrasse numa prisão, cujas paredes impedissem todos os ruídos do mundo de chegar aos seus ouvidos, não lhe ficaria sempre sua infância, essa esplêndida e régia riqueza, esse tesouro de recordações? Volte à atenção para ela. Procure soerguer as sensações submersas desse longínquo passado: sua personalidade há de reforçar-se, sua solidão há de alargar-se e transformar-se numa habitação entre lusco e fusco diante da qual o ruído dos outros passa longe, sem nela penetrar (RILKE, 1998, p.23-24).

Mas a vida efetiva de Ivan seguiu noutra direção. Ela perdeu-se no ruído dos outros. O frescor, a vitalidade e a unidade da infância foram substituídos pela eficiência e as promessas da erudição e das instituições.

(...) Quanto mais avançava [na vida] menos havia que lamentar. $O$ casamento, por mero acidente, depois o desencanto, o mau hálito da mulher e a sensualidade, a hipocrisia; depois essa mortífera vida burocrática e as preocupações de dinheiro, um ano, dois, dez, vinte e sempre a mesma coisa. 'É como se eu tivesse descido uma montanha pensando que estava subindo. Eis o que realmente ocorreu. Eu subia perante a opinião pública, mas na realidade a vida me fugia. E agora tudo acabou e só existe a morte' (TOLSTOI, 1997, p.79).

Que vida foi essa que fugiu? É a experiência da morte que está lhe mostrando toda a sua vida? Ivan chega a duvidar se realmente vivera como deveria ter vivido! Mas - prontamente responde - como seria isso se ele exatamente fez tudo como devia? Uma coisa, a vida que brotava na força da infância; outra coisa, a vida protocolar. Confundir a segunda como sendo a primeira, a vida primeira, parece ter sido o grande equívoco. E por quê? Nesta a vitalidade cedeu lugar à artificialidade. Tocava-o agora o vazio da vida repleta de burocracia. A supervalorização da vida comum e impessoal fechou-lhe os olhos e a mente para outras possibilidades de vida. Ivan insistia: 'Por quê? Será isto a Morte? E a voz interior respondia: "Sim, é a morte"; Por que este sofrimento? "Por nada - apenas" (TOLSTOI, 1997, p.81). Não há um porquê, não há razão, não há causa. Somente, nada. Nada, apenas nada. Quanto mais a doença progredia, cada vez menos se importava com a causa da morte, e cada vez mais o preocupava o sentimento da morte. Os tormentos 'morais' o perturbavam mais do que as dores do corpo. 'E se toda a minha 
vida estivesse realmente errada?' (TOLSTOI, 1997, p.86). Ocorreu-lhe não ter vivido a vida como devia. Os impulsos sufocados foram, a seu ver, mais verdadeiros. Todo o resto, trabalho, família, contatos, enfim, a vida como se deve, eram falsos. Mesmo assim tentou ainda, em vão, defendê-los. No entanto, não há mais nada a defender. A morte disse indiretamente a Ivan o lugar de sentido de todos estes valores sociais. Não somente porque não há mais tempo, já que Ivan está à beira da morte. Mas porque a sintonia com o fim apruma o olhar. Era assim, e é assim, a vida. Ser diferente, ser outra vida!? Como seria? Mas, ainda assim, seria uma vida determinada. Outra vida? Então, outra morte?

Apresenta-se a Ivan - e a Tolstoi - uma contradição de difícil solução: a vida social é composta de aparências, isto é, de representações sociais, adquiridas e fabricadas. Elas fornecem certo sentido à vida, conferindo aos indivíduos e às épocas seu caráter histórico. Mas, percebe-se que a supervalorização das instituições e das verdades estabelecidas causa um mal ao indivíduo e à vida social. Todas as aparências que compõem a sociedade, de certa forma, são falsas. Mas elas não são, em geral, vistas desse modo! Sem essa falsidade e sem esses artificialismos torna-se impossível tanto a existência de uma vida comum quanto de uma vida individual. $\mathrm{O}$ social e o individual contrapõem-se e mantêm-se numa eterna tensão. $O$ fato de não se poder destruir a falsidade da vida - 'é assim, a vida' - significa que a aparência compõe a vida, que não há como fugir de todo artificialismo. Como seria uma vida sem aparencia? Seria, ainda, a vida? A solução não reside, então, na extinção de toda aparência trazendo à luz, e para todos, o que está oculto verdadeiramente sob todas as aparências. Pois este 'oculto', para ser visto, necessitaria de alguma aparência ${ }^{5}$. O oculto seria novamente transformado em aparência. Há de se buscar uma mudança da compreensão. O problema está ainda em como Ivan - e o ser humano - se relaciona com a vida e com as aparências. Ivan não via a vida protocolar como aparência! Como o ser humano compreende a vida e, de certa forma, que compreensões dominantes colaboram antes para um estreitamento de sua visão da vida do que para um alargamento? Ivan já sempre compreendeu algo da vida e da morte. Mas o entendimento atual não esgota o entendimento do possivel. A nova compreensão pensada por Tolstoi - caracterizada como uma inversão - aposta na mudança do indivíduo, corrompido pela sociedade. Este novo indivíduo formará, então, outra sociedade. Mas, como o leitor já deve ter percebido, optamos fundamentalmente por uma leitura ontológico-existencial. Esta torna visível e pensável o interesse de Tolstoi sem estigmatizá-lo ingenuamente como um mero idealista. O modo próprio de ser do humano se torna aí visível.

Ivan passou sua vida em revista: os comportamentos dos médicos, da esposa, da filha e do filho, dos criados. A vida impessoal que todos viviam e

${ }^{5} \mathrm{Cf}$. tb. o pequeno comentário que fizemos acerca da noção de verdade no início deste trabalho. 
tinham de viver, bem como os diversos papéis representados socialmente. Tudo era uma enorme e horrenda mentira. E ninguém percebia ou tinha consciência disso. Esta mentira escondia dos viventes a dinâmica constitutiva da vida e da morte.

\subsection{A agonia de Ivan}

As reflexões finais possuem algo de fantástico. Entram no impossível, se tomarmos como referência a realidade cotidiana. Mas esta não é, para nós, a única possibilidade. De fato, há só silêncio. Nele acontece o essencial: a agonia de Ivan. Que ver aí? Que esperar desta conclusão de Tolstoi?

Em certo sentido, ninguém pode fazer a experiência da própria morte: quando estou vivo, é o outro que morre; quando morro, não posso sobreviver à minha própria morte para relatá-la aos outros. Quem morre, então, é sempre o outro. Conseqüentemente, todo discurso acerca da morte própria, particular, possui algo de inadequado. Podemos estender este raciocínio para diversos discursos acerca da morte: o da psicologia, na sociologia, na medicina, na religião, etc. A morte própria é algo de derivado e uma impossibilidade investigativa. Da morte enquanto aquela que a mim, e somente a mim pertence, se fala secundariamente, por figuras de linguagem. Mas nesta situação constata-se, positivamente, a existência de um problema. Talvez de caráter aporético. E o caminho de reflexão, sugerido por Heidegger, passa pela incorporação de existenciais tais como antecipação e possibilidade.

Quando percebemos esta situação - a história de Ivan nos levou a isso - reconhecemos um estranho espaço e tempo que nos inquieta: o da particularidade ou singularidade ou propriedade. Estamos diante da grande experiência limite, na qual o saber e a linguagem comuns silenciam. E silenciam porque agora já não fala mais o corriqueiro e social. Que fazer aí? De início, a vida social cotidiana cria mecanismos para escapar deste paradoxo. Que fazer aí quando nada se pode fazer? Ouvir, silenciar, deixar ser? Nada disso nos agrada. Mas neste desagrado outra palavra elabora sua mensagem. $\mathrm{O}$ sentimento que nos toca agora é o de nós mesmos nos tornarmos a matéria ou a lenha desse fogo. Nós teóricos somos convidados à experiência da inversão, como já dito, a ver e pensar a partir da experiência da morte. Mas inverter, neste caso, não consiste numa mera troca de posição ou de ponto de vista: ou a partir da vida ou a partir da morte. A inversão, à medida que se impõe, mostra-se como uma perspectiva que tem a capacidade de modificar a vida em sua totalidade. Melhor: a partir da inversão, a experiência da morte mostra-se não simplesmente como sendo outro pólo, mas a estrutura nevrálgica do ser humano. $\mathrm{Na}$ inversão e a partir desta a vida é intensificada em sua percepção e compreensão. É a partir dela que algo de próprio vem a ser. Este 
comportamento possível - de ser a partir da morte - 'nunca torna as coisas mais fáceis senão apenas mais graves’ (HEIDEGGER, 1987, p.41). Desta forma, o momento limite pode nos libertar para a compreensão do que vem a ser limite e, aqui, das aparências sociais: compreendê-las como elas são e não como aquilo que nós, desavisadamente, gostaríamos que elas fossem! Compreender todos os véus naquilo que eles são: possibilidades da existência. Afinal, Ivan não sobrecarregou a vida? Não quis demais? Não quis que a vida lhe oferecesse o que ela essencialmente não poderia dar?

De fato, 'o “morrer” é da ordem do insubstituível' (DUBOIS, 2004, p.49). Semelhante percepção nos joga numa experiência existencial: a morte é de cada um, inapreensível aos outros e, por outro lado, enquanto nós vivemos, nós dela sabemos em algum grau. Um aceno disso pode ser visto quando nos tocamos de que a morte tem algum sentido para nós. E quando percebemos na morte uma experiência insubstituível já não estamos mais a falar de um saber ao estilo da lógica. Nós dela sabemos antecipadamente, por exemplo, à medida que dela fugimos nas doces ilusões de uma vida correta. Por isso, diante desta possibilidade, podemos também perguntar acerca de um modo de antecipação distinto e 'teórico', um modo que tem como prática sua o exercício de retirar o indivíduo desta anestesia da vida que é estar continuamente misturado e escondido nas teias do impessoal. Este comportamento radical e próprio possui o caráter de uma opção ou escolha antecipada pela morte, ou seja, pela inversão como perspectiva fundamental da existência. Não há aqui nenhuma afeição corriqueira pela morte como tantas vezes se vê.

Ivan lutou contra a morte por ainda três dias. Quase não falava. Imaginava a morte como um saco negro. $\mathrm{O}$ que não o deixava morrer era ainda aquele sentimento de que a vida fora boa. E não a abandonava. Achava ainda que a vida insubstituível pudesse ser retificada. Observava seus familiares. Teve pena do filho e da mulher. "Descanse", falou à esposa. E à própria dor: "Deixe a dor doer" (TOLSTOI, 1997, p.91). Ele não queria mais que os outros sentissem pena dele, não queria mais ser compreendido ou que entendessem as suas razões. Agora ele sentia pena (...). E a morte? 'Procurou o temor cotidiano da morte e não o encontrou'. 'Não havia temor porque não havia morte' (TOLSTOI, 1997, p.91). Ganha proeminência uma série de inversões, isto é, de um ponto de vista a partir da experiência da morte e não mais a partir da vida social. Ivan não quer mais que sintam pena dele, ele é que sente; não quer mais suprimir a dor, deixa-a doer; já não teme mais como antes, quando se orientava unicamente pelo social. Não bá mais o que temer. A morte era algo, um ente ameaçador, temível? Agora ela já não é mais 'algo'. Que é ela então? Ela que já 'não há'? Nela se apresenta, ontológicoexistencialmente, o modo de ser do humano, continuamente desfocado nas teias sociais. Assim, não há morte. Há isso que somos! Também entendemos que esta colocação nada tem a ver com uma possível extinção de toda finitude, de 
tal forma, que o ser humano 'viveria para sempre'. Por assim dizer, é o estatuto da morte que se modificou. Tal como a luz, a morte se mostra como 'aquilo' a partir da qual toda a existência prévia ou anterior é desnudada e se torna visível. Mas o que torna visível a existência não é, em si mesmo, visível. Não é coisa, não é ente, não é algo. O que 'não é' não pode ser temido como se fosse alguma coisa.

O temor cotidiano da morte apenas é sentido à medida que se vive uma vida impessoal, onde quem vive é a representação social, algo como 'ninguém', e que teme a perda do status, do lugar herdado ou adquirido. E por que 'ninguém' - em suas expressões institucionais - deva ser algo mais forte que 'alguém'? $\mathrm{Na}$ ausência deste temor cotidiano da morte, ela, a morte, pode ser experimentada e compreendida como pertencendo à vida, e não como sua contradição. Estranha compreensão! Ora, a morte é temida porque ela põe fim a esta vida impessoal e a todos os seus valores. Se e enquanto a vida impessoal for o único ponto de referência, então também se justifica o temor. Quem teme é quem não quer perder algo porque considera a perda, toda a perda, como um equívoco! Toda instituição tende à durabilidade, nos ensinam os sociólogos. Toda existência é finita, histórica, localizada, provisória, nos ensina a trajetória de Ivan e a perspectiva filosófica que nos orienta. Não havendo mais o temor, não há mais a morte, tal como foi sempre experimentada em suas variadas representações. Mas, o que há então? Que experiência é esta? Para o artista se trata de algo mais sério e primordial do que toda representação social.

Tolstoi descreve esta existência transformada como experiência de totalidade, de unidade, de 'tornar-se inteiro'. Ivan viveu uma vida cindida. Uma vida de fuga do que lhe pertence propriamente e sempre. Também, então, uma fuga de si. A sua morte lhe trouxe a unidade esquecida. "Acabou a Morte", pensou. "A morte já não existe!" Aspirou profundamente, interrompeu a respiração, inteiriçou-se e morreu' (TOLSTOI, 1997, p.91). Quando, tal como Ivan, se exige que o fim seja e esteja sob controle (como a vida), a própria vida já perdeu o seu essencial frescor, todo o seu caráter de possibilidade (de criação e de futuro). Se a vida é, para algum homem determinado, tal como ela não deveria ser, inevitavelmente este homem se tornará amargurado e revoltado. Se a morte é possível a cada momento, e o ser humano disso se dá conta, então vivendo a cada momento ele é tocado por este elemento indomesticável, ilógico, originário, 'pré-científico' que compõe a existência humana. O que pode derivar deste toque essencial?

Ivan continuamente sente a presença da morte, sua implacável certeza incerta e, por outro lado, tem a saudade de outro tempo. A dor e o sofrimento remetem a um modo de ser impessoal que resiste. Assim foi toda a vida de Ivan. Por outro lado, seria a nosso ver uma rasa interpretação considerar que a conscientização do que foi ignorado em vida se revertesse numa forma de 'enganar a dor'. A consciência da morte não se mostra como 
uma técnica individual para burlar a dor. Ontologicamente, na negação da dor e da morte que se delineia (não há mais dor, não há mais morte) elabora-se a incorporação da morte na vida e da vida na morte. A dor só dóil Supera-se a dicotomia: ou vida ou morte. No entanto resistimos: como tornar isso mais visível? Através de uma mutação do olhar e/ou do deslocamento de seu foco de atenção. Ivan (bem como nós!) acostumou-se a ver a morte como um substantivo, como 'algo', o nome 'morte', essa 'coisa simplesmente existente' que ocorre em algum lugar indiferente no futuro. Portanto, como 'algo' fora e aquém de quem morre. A morte não lhe dizia respeito. Agora, Ivan é convocado pela força dos fenômenos - está a morrer! - a ver a morte em seu vir a ser, a ver o verbo morrer, aquele que já sempre esteve consigo desde sempre como a possibilidade mais própria, o verbo que, ontologicamente, é o responsável pela descoberta de sua vida como finita e como uma tarefa criativa que precisa sempre de novo ser inventada, enfim, pelo frescor da vida. Mas, por que 'assim'? Porque o verbo possui tanto a força de erosão de tudo o que foi institucionalizado, quanto o poder de devolver o ser humano ao seu modo de ser constituinte. O ser humano, morrendo, descobre o que sempre foi, é e será: uma vida como tarefa de ser. Ivan, em certo sentido, delegou esta responsabilidade vital à sociedade e não a si. A descoberta da morte como o 'meu morrer' libera a 'minha vida' para ser vivida não exclusivamente como 'esta' realidade determinada. 'Mais elevada do que a realidade está a possibilidade' (HEIDEGGER, 2006 a, \$7, p.78).

O nascimento da consciência da morte não possui a forma de alguma informação ou constatação, mas de uma transformação da auto-compreensão do personagem e, por extensão, do ser humano (do Dasein). Nesta ambigüidade típica apresenta-se a estrutura da vida social e impessoal: ela nunca escolhe ou opta pelo indivíduo, pelo si mesmo de cada um, mas sempre pelo geral e universal. Fazer a opção pela própria morte, aquela desconhecida e velada na vida social, implica numa estranha experiência, a de morrer (e viver!) a própria morte e não mais a morte indiferente de todo mundo. Mas como isto é possível? Como tornar isso compreensível? Por certo, se observarmos apenas o curso estético da novela acataremos os absurdos e a saída fantástica de Tolstoi como inacessível a toda gente e, portanto, apenas como uma palavra 'literária'. Mas não é o único caminho, já o dissemos. Talvez Tolstoi esteja a pensar no leitor que, de fato, ingressa no silêncio e na nudez do ego sum moribundus, onde a morte não é algo de acidental, ocasional ou fortuito que, talvez, sobrevenha (Cf. HEIDEGGER, 2006 b, \$34 p.395). Uma possibilidade co-movente de leitura. Um novo horizonte de compreensão que se disponibiliza ao olhar pensante! O ser humano já sempre foi mortal. A fuga da morte presente no mundo social corresponde a uma contínua fuga de si mesmo. Mas na fuga sempre se mostra a presença constante no aqui e agora do ser que se é, daquele ser 'do qual' se foge (angústia, ser-para-a-morte). O ser mortal moribundo - constitui-se como a identidade própria do ser humano. Não há 
mais porque esperar a morte, esperar o que já sempre veio! O morrer, o ser moribundo enquanto se é, é que lhe confere sentido ontológico. Mas como o leitor poderá compreender isso? Como Tolstoi ou Heidegger poderão obter sucesso na transmissão desta experiência de fundo para o leitor? A opção pela morte, pelo morrer, possui a característica de uma decisão por si mesmo. Nada tendo a ver com algum desejo de suicídio (o que seria uma fuga da morte própria). A decisão pela morte - ser-para-a-morte -, ou seja, assumir o morrer que já sempre me pertenceu, desperta ou faz o ser humano nascer para a tarefa de sua própria existência como intransferível. 'O antecipar-se até a morte a todo momento do Dasein significa sair do impessoal e recolher-se ao Dasein, no sentido de optar por si mesmo’ (HEIDEGGER, 2006 b, §34 p.397). ‘O "propriamente morrer" exprime uma relação do Dasein com seu fim incontestável que o impregna a partir de seu aparecimento na mundanidade' (SCHUMACHER, 2009, p.111). Ou seja: desde sempre.

\section{Considerações finais: uma reflexão filosófico-sociológica}

A vida que de início se apresenta é a social, aquela da convivência no trabalho, no lazer, na família, seu status e seus modelos ideais. Podemos ver aí, também, um eco daquele fenômeno que nos assola desde o século XIX, o da morte - e da perda de sentido absoluto - daqueles valores superiores que determinavam a existência efetiva. A crítica de Tolstoi à sociedade pode ser explorada, em certo sentido, como a morte de uma concepção de sociedade. Nesta novela desconcertante de Léon Tolstoi a morte ocupa o lugar central. É ela que permanece indiferente a todos os projetos humanos. Em certa medida, seu advento é a história da paixão e morte de Ivan, de sua dor de ser e, por que não, da nossa. Neste sentido, trata-se da morte de alguém, alguém histórico, e não do fim de um ninguém ou de uma vida biológica qualquer.

O título escolhido para este texto apresentou-nos uma interpretação que tomou como ponto de partida a vivência cotidiana e impessoal em que o personagem e nós mesmos nos encontramos. Ali, a vida e a morte são vistas como eventos corriqueiros, estatísticas, fenômenos sociais passíveis de registro e de quantificação em determinada escala, como generalidades ou universalidades, que pertencem a todo mundo e que, portanto, não devem causar surpresa, nem nos assustar em demasia e, a rigor, devem atender a um protocolo, por mais que ele nos 'deprima' (isto, ainda, faz parte do protocolo!): toda gente deve viver e morrer como se deve. Estas normas sociais retiram sua medida das instituições mais diversas, tais como o Estado, a Igreja, a Justiça, mas também, a Ciência e os Costumes do tempo. Já sempre encontramos a vida e a morte atreladas às nossas efetivas e indiferentes existências. Por outro lado, estes mesmos critérios institucionalizados provêm de algum lugar exterior à vida e à morte efetivas, de algum lugar que, aparentemente e a rigor, 
não vive nem morre, não está sujeito às vicissitudes da vida e da morte. Pois a morte individual é, a partir do que domina estas instituições, algo de estranho, como um intruso que, afinal, vem. Vida e morte efetivas - a partir delas mesmas tornam-se fenômenos secundários. Assim, vida e morte acontecem nestes contextos institucionais, mas estes mesmos contextos imprimem um sentido à vida e à morte a partir de suas próprias interpretações especializadas, lógicas e genéricas. Por isso este lugar dos contextos institucionais, lugar um tanto eterno, permanente, supra-sensível, 'metafísico', possui algo de impessoal: acima dos casos individuais e particulares e no direito de explicá-los ou interpretá-los. Estes contextos ditam a vida, dizem como ela deve ser. A vida ela mesma é destituída de sua vitalidade ou seu frescor. A alegria e a dor, o prazer e o desprazer, a seriedade e a diversão, a admiração e a indignação, etc., que ali vigora é a alegria e a dor, etc., de todo mundo, isto é, de ninguém.

Ainda em seu último grande romance, Ressurreição (1899), Tolstoi nos apresenta este dever sobre-humano institucional e metafísico, causador das mais absurdas injustiças e de sua correspondente ausência de culpa, como o serviço de Estado. Ferozmente, ele nos diz que

\begin{abstract}
(...) existe um trabalho chamado serviço do Estado, no qual é possível tratar as pessoas como se fossem coisas, sem relações fraternas e humanas com elas, e em segundo lugar que essas mesmas pessoas do serviço do Estado estivessem unidas de tal forma que a responsabilidade pelo resultado de suas ações para as outras pessoas não recaísse em ninguém isoladamente (TOLSTOI, 2010, p.338).
\end{abstract}

Vivemos a vida como se deve, desempenhando alguma função e, nela, atendendo a um conjunto de obrigações. E, no fundo, importando-nos com os outros apenas à medida que sua vida se enquadra nas nossas obrigações. Nós e os outros, mais ou menos, tratamos e somos tratados como coisas, isto é, de forma indiferenciada. Nesta direção, mas não exclusivamente, segue boa parte da crítica social e do pensamento filosófico de Tolstoi.

Chamou nossa atenção a descrição da vida social, caracterizada pela impessoalidade, e o sofrimento do personagem que é, a um tempo, excluído pelos outros como se estivesse a fazer algo equivocado (adoecer, morrer...), e noutro tempo, que deseja ser e retornar ao modo de vida dos outros (que é o seu!), à vida corriqueira de toda gente, uma vida comum e sem abalos. Ivan não conhece outra vida! E toda outra vida sempre terá alguma máscara, isto é, não será - enquanto vida humana - construída fora da sociedade. Assim, é possível ter olhos para uma vida outra, diferente desta? Em que sentido?

O caso é que a experiência da dor não foi sentida de início como sendo a sua própria ou como constituindo desde sempre seu ser. Ela foi abordada como um equívoco, um mal-entendido, um índice da falta que os outros the faziam. Não podemos deixar de nos incomodar com semelhante história, pois a 
ficção é por demais real. Ela nos fala de uma vida efetiva, que vive e que sente $a$ partir de outra vida, ideal e, de certo modo, ilusória. Uma vida geral que se sobrepõe em todos os sentidos a uma vida particular. A ficção produzida por Tolstoi possui o devido afastamento e a saudável distância que pode nos aproximar modestamente de nossa situação humana no mundo, a saber, da percepção de nossa efetiva existência, em geral desviada exclusivamente para as ocupações e preocupações do entorno social. O problema então assim se mostra: falar e pensar a vida, a vida que vivemos e que sentimos a partir dela mesma! E não a partir do que ela deveria ser! Como é a vida a partir dela mesma? A compreensão que temos da vida sofre uma modificação ontológica. $\mathrm{O}$ autor faz, a seu modo, uma crítica da sociedade e de suas instituições jurídicas, burocráticas, científicas..., e valoriza o indivíduo, a vida simples campesina (o mujique, o mundo rural), construindo diversos exemplos de forma caricata, exagerada, o que sempre é um luxo e uma felicidade para a reflexão. É no plano do indivíduo, do simples, do rural - fora das instituições burocráticas do Estado - que Tolstoi vê a redenção da sociedade e do homem moderno. Como atingir esta redenção? Considerar este posicionamento de Tolstoi como uma mera inversão, igualmente idealista, será exatamente esquivar-se do problema vital que se apresentou na morte de Ivan. Mas não interpretamos o autor como um militante às avessas, oposto simplesmente ao serviço de Estado. Embora reconheçamos esta possibilidade de leitura! Nós tratamos o autor como um diagnosticador de seu e do nosso tempo. Alguém que tem olhos para o que raramente se vê. Em todo caso, sempre estamos às voltas com a pergunta: que quer dizer 'chão, simples, individual, pessoal'?

Tendo a descrição deste ambiente como ponto de partida, o livro nos conduz a um conjunto de noções acerca da morte e da vida intransferíveis, únicas, nossas, isto é, 'minhas', próprias. A morte própria não é atingida como uma evidência geral e universal, como um conceito acessível a todo mundo, mas como sentimento inquietante, uma ausência e desconhecimento das palavras adequadas, uma relação com o próprio ser, um silêncio perturbador. Por isso, os últimos diálogos dão-se no ambiente do silêncio: o personagem e sua morte. Não se encontra, nem se encontrará, na morte 'própria' (e o que quer que ela signifique) uma resposta universal, válida, como uma moeda de troca geral e aceita por todos. Se assim fosse, de chofre, fugiríamos do impacto causado pelo que há de peculiar nesta experiência (a morte é sempre minha!) e, novamente, nos refugiaríamos na convivência impessoal e indiferente. Mas pode-se encontrá-la como uma tarefa, estranha tarefa, que pode se abrir como possibilidade a cada um: isso quando optamos por ela, quando a escolhemos! A partir desta decisão - que não tem nada de arbitrário - nasce uma reflexão a partir da vida ou existência elas mesmas! Mas Ivan somente o faz no silêncio de seu momento fatal, diríamos. O artista-autor está a pensar no leitor e no poder da leitura e da interpretação para a modificação social. Assim nos parece. E, por isso, justifica-se também o aspecto real e efetivo da abordagem do fenômeno 
da morte como uma experiência antecipada. Para este ponto caminhamos em nosso percurso. A noção heideggeriana de 'próprio' nos revela a textura de comprometimento desta pessoalidade onde se opta antecipadamente pelo que há de mais próprio, a morte. Opta-se pelo modo de ser do bumano que é, desde sempre, antecipação, possibilidade. A opção antecipada não possui aquele aspecto presente nas escolhas efetivas - de ir ao cinema, escolher um partido, optar por uma profissão, manifestar uma opinião, etc. - mas a forma estruturante de uma opção pelo 'verbo' ou pela tarefa de ter que, a cada vez, conquistar seu ser sem o consolo de alguma sobre-humana instituição. É a opção por si mesmo ou a experiência de propriedade. Desta distingue-se aquela em que as opções já estavam decididas dentro dos projetos ou ideais institucionais. Lá se vivia uma vida - como a de Ivan - que não era aquela desejada!

Assim, a vida própria não possui a face de uma essência por detrás das aparências sociais e genéricas. Possui antes a face de uma intensificação do drama da vida que se expressa na opção por si manifestada a partir da sintonia com o momento limite da morte. A consciência do acontecimento de nossa finitude traz em seu bojo a escolha singular pelo indivíduo, isto é, pelo próprio, pelo insubstituível e irremissível do ser existente que cada um é. A partir disto tudo pode se modificar.

A indiferença da morte de ninguém pode ceder lugar à produção das diferenças, dos casos particulares, do individual e do singular, do insubstituível e, por isso, do incomparável e do terrível. O elemento próprio ultrapassa em muito aqueles aspectos individualizantes e autoafirmativos que o mundo moderno produziu como identidade sua. Ele pode, sobretudo, ver toda tentativa de eternidade com outros olhos, isto é, as instituições talvez nada mais sejam do que 'mausoléus e túmulos de deus' (NIETZSCHE, 2001, N.125, p.148), fato esse que poderá, lentamente, despertar na mente dos leitores. Os aspectos próprios não se deixam encaixar em categorias universais. Sua percepção é de outra ordem. Ontologicamente podem não negar, mas se apropriar da vida institucionalizada de modo distinto. Acompanhar a tragédia de Ivan é partilhar da aventura humana, que nos pertence pelo fato de existirmos e de não podermos não existir. Pertence a esta aventura sempre o perigo de esquecê-la no conforto, na segurança e nas ilusões institucionais.

Nossa interpretação remeteu a novela de Tolstoi à obra de M. Heidegger. Em Ser e tempo Heidegger lembra $A$ morte de Ivan Ilitch: 'Não é raro perceber a morte dos outros como um desagrado e até mesmo como uma falta de tato social contra que o público deve precaver-se' (HEIDEGGER, 2006 a, $\$ 51$, p.330). Percebemos, aqui, a simpatia entre os textos. Mas Heidegger quer que percebamos algo a mais no livro em questão. Diz ele na nota de rodapé da mesma página: 'Em seu conto (...), Tolstoi expôs o fenômeno do abalo e do colapso desse "morre-se impessoal" (man stirbt)'. E o que significa isso? Trata-se de uma orientação que completa as observações nossas anteriores. Quem morre? De fato: Ivan. No entanto: como é a morte de Ivan? O que morre na morte de 
Ivan, em seu percurso trágico e a partir do ponto de vista desta morte, é a própria impessoalidade 'burguesa' (QUILLIOT, 2000, p.173) - inteligente, agradável e correta - na qual Ivan sempre viveu. Em morrendo, morre junto com Ivan, todo o artifício de uma vida construída como se deve. Uma vida que se vê e se pensa como infinita, eterna, durável, exemplar, a mesma para toda gente. A nosso ver a obra se mostra como um trabalho minucioso de desnudamento. É a história do abalo e do colapso do impessoal que jaz em toda gente, nos outros e no personagem, condição sine qua non para qualquer discussão acerca de uma morte e uma vida próprias.

Mas, retrocedendo desta posição, poderíamos objetar - contra Heidegger - que Tolstoi visa a uma metamorfose social, um retorno ao simples e campesino da vida humana, a uma nova humanização da sociedade, a uma nova moral.

Depois de tudo isso, que outra coisa é a experiência
transformadora da morte para Ivan Ilitch distinta da reação
moral que o sufoca pela vida que tem levado? Essa vida, que
parecia tão 'normal' e aceitável para ele e seus pares sociais,
agora se mostra egoísta, vazia, vaidosa e, portanto sem
sentido. Com isso também surge a visão de outra e diferente
forma de vida que os homens deveriam viver. Esta é a
verdade, a revelação, a Alétheia, que a iminência da morte traz
consigo. A análise existencial de Heidegger torna explícita
uma estrutura ontológica implícita na novela de Tolstoi, mas
deixa de fora a mensagem moral que está em seu centro
(BARRET, 2001, p.233-234).

Por certo, a iminência da morte traz uma revelação ou pode trazê-la. Todo o anterior sofre uma nova ressignificação. E pode-se ver em Tolstoi a proposta de uma nova moral para a sociedade. A nosso ver, no entanto, o comentador acima reivindica muito rapidamente para a experiência da verdade como alétheia uma determinação moral. Pois uma nova moral, possibilidade sempre em aberto, traz consigo as ilusões características de qualquer nova organização social. Entendemos que a revelação - alétheia - a partir da iminência da morte possui sentido distinto e já presente na interpretação heideggeriana. É o que expressa em sua Carta sobre o bumanismo: 'O pensar que pergunta pela verdade do ser, determinando aí a morada [ethos] essencial do homem a partir do ser e na direção do mesmo, não é ética nem ontologia' (HEIDEGGER, 2008, p.370). Então, será propósito de uma ontologia fundamental - a analítica do Dasein - e que se distingue de outras ontologias, fornecer uma mensagem moral, um modus vivendi renovador? É este o papel da filosofia? Devemos nós esperar uma moral da análise e explicitação teórica da filosofia? Por certo, esperar da filosofia - ou de alguma doutrina - uma orientação, mostra-se como sendo uma possível compreensão da mesma. Mas não a única. Heidegger expressa uma perspectiva 'moral' à medida que aponta 
para a morada do homem, para o seu modo de ser ou comportamento estruturante. Este caminho se contrapõe àquilo que corriqueiramente se entende por moral e por ética. Assim, e trabalhamos neste sentido, existenciais como angústia, nada, morte, compreensão, verdade como desvelamento, etc., e mesmo 'metafísica', etc., apontam para o retorno ao mais próprio do ser humano.

Que fazer diante e a partir desta experiência extrema, a da morte? Que fazer filosoficamente diante do que nada se pode fazer? Apenas cuidar on guardar, como diz o poeta Antonio Cícero. Cuidar do ser que somos e que é, a partir de seu ser, só cuidado. Então, um esforço de correspondência. Neste contexto podemos apresentar a tarefa da filosofia como tão só um esforço de correspondência com nosso ser.

\author{
Guardar \\ (Antonio Cícero) \\ Guardar uma coisa não é escondê-la ou trancá-la. \\ Em um cofre não se guarda coisa alguma. \\ Em cofre perde-se a coisa à vista. \\ Guardar uma coisa é olhá-la, fitá-la, mirá-la por admirá-la, \\ isto é, iluminá-la ou ser por ela iluminado. \\ Guardar uma coisa é vigiá-la, isto é, fazer vigília por ela, isto \\ é, velar por ela, isto é, estar acordado por ela, isto é, estar por \\ ela ou ser por ela (CÍCERO, 1996, p.337).
}

\title{
Referências
}

ARIES, Philippe. O homem diante da morte. Rio de Janeiro: Ed. Francisco Alves, 1989.

BARRET, Willian. La ilusión de la técnica. Santiago de Chile. Editorial Cuatro Vientos, 2001, p.233-2.

BORGES, Jorge Luis. Cinco visões pessoais. Brasília: Editora Universidade de Brasília, 1987.

CÍCERO, Antonio. Guardar. In: Poemas escolbidos. Rio de Janeiro: Editora Record, 1996.

DUBOIS, Christian. Heidegger: introdução a uma leitura. Rio de Janeiro: Jorge Zahar Editor, 2004. 
ELIAS, Norbert. A solidão dos moribundos. Envelhecer e morrer. Rio de Janeiro: Jorge Zahar editores, 2001.

FREUD, S. Reflexões para os tempos de guerra e morte. Rio de Janeiro: Imago, 1974.

HEIDEGGER, Martin. Ser e tempo. Petrópolis: Vozes, 2006 a.

- Prolegômenos para una historia del concepto de tiempo. Madrid: Alianza editorial, $2006 \mathrm{~b}$.

. Introdução à metafísica. Rio de Janeiro: Tempo Brasileiro, 1987.

. Marcas do caminho. Petrópolis: Vozes, 2008.

KÜBLER-ROSS, Elizabeth. Sobre a morte e o morrer. São Paulo: Ed. Martins Fontes, 1989.

LISPECTOR, Clarice. A hora da estrela. Rio de Janeiro: Nova Fronteira, 1984.

NIETZSCHE, F. W. A gaia ciência. São Paulo: Companhia das Letras, 2001.

PESSOA, Fernando. A última nau. In: Obra poética. Mensagem. Volume único. Rio de Janeiro: Nova Fronteira, 2007.

QUILLIOT, Roland. Qu'est-ce que la mort? Paris: Armand Colin, 2000.

RILKE, Rainer Maria. Cartas a um jovem poeta. São Paulo: Globo, 1998.

SCHUMACHER, Bernard N. Confrontos com a morte. São Paulo: Ed. Loyola, 2009.

TOLSTOI, Leão. A morte de Ivan Ilitch. Rio de Janeiro: Lacerda editores, 1997. . Ressurreição. São Paulo: Cosac Naify, 2010.

Email: eciopisetta@gmail.com

Recebido: 09/2016

Aprovado: 12/2016 